\title{
Article
}

Mycosphere

\section{Antibacterial activity, optimal culture conditions and cultivation of the medicinal Ganoderma australe, new to Thailand}

\author{
Luangharn $\mathrm{T}^{1,2}$, Karunarathna $\mathrm{SC}^{1,2}$, Khan $\mathrm{S}^{1,2}, \mathrm{Xu} \mathrm{JC}^{, 2^{*}}$, Mortimer $\mathrm{PE}^{1,2}$ and \\ Hyde KD ${ }^{1,2,3,4,5}$
}

\author{
${ }^{1}$ Key Laboratory of Economic Plants and Biotechnology, Kunming Institute of Botany, Chinese Academy of Sciences, \\ 132 Lanhei Road, Kunming 650201, China. \\ ${ }^{2}$ World Agroforestry Centre, China \& East-Asia Office, 132 Lanhei Road, Kunming 650201, China.3 \\ ${ }^{3}$ Center of Excellence in Fungal Research, Mae Fah Luang University, Chiang Rai 57100, Thailand. \\ ${ }^{4}$ School of Science, Mae Fah Luang University, Chiang Rai 57100, Thailand. \\ ${ }^{5}$ Mushroom Research Foundation, 128 M.3 Ban Pa Deng T. Pa Pae, A. Mae Taeng, Chiang Mai 50150, Thailand.
}

Luangharn T, Karunarathna SC, Khan S, Xu JC, Mortimer PE, Hyde KD 2017 - Antibacterial activity, optimal culture conditions and cultivation of the medicinal Ganoderma australe, new to Thailand. Mycosphere 8(8), 1108-1123, Doi 10.5943/mycosphere/8/8/11

\begin{abstract}
Ganoderma is a well-known genus of medicinal mushrooms that belongs to the order Polyporales. Many members of this genus are extensively used in traditional Asian medicines. Herein we report a new strain of Ganoderma australe collected in Thailand and identified using macro- and micro-morphological characteristics as well as phylogenetic analysis. The optimal conditions for mycelia growth were $25-30^{\circ} \mathrm{C}$ at $\mathrm{pH} 7-8$, while sorghum and barley were found to be the best grain media for spawn production. The best medium for mycelia growth was Potato Dextrose Agar (PDA) medium. Para rubber sawdust with organic and inorganic additives is used as a standard cultivation substrate in Thailand. The mycelia were fully distributed throughout the sawdust substrate after being incubated at $30^{\circ} \mathrm{C}, 60-75 \%$ relative humidity for 18 days. The first primordia were observed three days after the bags were opened. Three fruiting cycles were obtained, although the weight of mushrooms produced decreased each time $\left(115.04 \pm 48.85 \mathrm{~g} \mathrm{~kg}^{-1}, 72.01 \pm 6.00 \mathrm{~g} \mathrm{~kg}^{-1}\right.$ and $36.47 \pm$ $9.04 \mathrm{~g} \mathrm{~kg}^{-1}$, respectively). Extracts of G. australe inhibited Micrococcus luteus, Bacillus subtilis, Staphylococcus aureus and Salmonella typhimurium bacteria however, the extracts were not effective against Escherichia coli and Pseudomonas aeruginosa. This is the first report of the antimicrobial activities observed in G. australe.
\end{abstract}

Key words - Lingzhi - Primordia - Rubber sawdust - Shorea robtusa

\section{Introduction}

Ganoderma P. Karst. established by Karsten (1881), belongs to the family Ganodermataceae, and is typified by G. lucidum (Curtis) P. Karst. This taxon is commonly known as Lingzhi in China or Reishi in Japan (Chang \& Buswell 1999). This genus is characterized by its unique laccate or nonlaccate species and particularly by its double-walled basidiospores (Moncalvo \& Ryvarden 1997). Ganoderma is a cosmopolitan genus known to cause white rot of woody material (Smania et al. 1999, Gao et al. 2003, Gerber et al. 2000, Rofuli et al. 2005, Upadhyay et al. 2014, Baby et al. 2015, Rai et 
al. 2015, Cilerdzic et al. 2016). Several studies have shown that the genus is morphologically highly variable, often resulting in taxonomic and phylogenetic confusion, especially with regards to $G$. lucidum (Moncalvo et al. 1995, Hapuarachchi et al. 2015).

Ganoderma mushrooms have been used for over two thousand years in traditional medicine in China, Korea, Japan and Taiwan and other Asian regions (Anonymous 1955, Pegler 2002, Paterson 2006, Batra et al. 2013). Some species have been used in medicines to prevent and treat human diseases (Paterson 2006) such as hypertension, hypercholesterolemia, bronchitis, asthma, diabetes and cancer (Mizushina et al. 1999, Wasser 2005, Zmitrovich et al. 2006, Sadava et al. 2009, Smania et al. 2007, Fatmawati et al. 2010, Chang \& Wasser 2012, De Silva et al. 2012a, b, De Silva et al. 2013). Species of this genus are rich in biologically active compounds, especially triterpenoids and polysaccharides, which play critical roles in a variety of biological effect (Isaka et al. 2013, Baby et al. 2015). As a result, these medicinal Ganoderma species have become a popular dietary supplement with great economic value (Ofodile et al. 2005, Liu et al. 2010).

Although 22 Ganoderma species have been described worldwide, only nine species have been domesticated viz. G. applanatum (Zhou \& Zhang 2015), G. amboinense (Hiroo 2008), G. lucidum (Wang et al. 2012, Kamra \& Bhatt 2013, Roy et al. 2015), G. neojaponicum (Jo et al. 2010, Tan et al. 2015), G. gibbosum (Zhiqun \& Ziwu 2011), G. resinaceum (El-Fallal et al. 2015), G. tropicum (Liu et al. 2009), G. tsugae (Adaskaveg \& Gilbertson 1986) and G. austral (Papaspyridi et al. 2009), Recently, a specimen of $G$. australe was collected and isolated from Thailand; previously this species was only known from New Zealand (Buchanan \& Wilkie 1995), southern India (Yeh \& Chen 1990, Kaliyaperumal \& Kalaichelvan 2008) and Taiwan (León et al. 2003). Steroids, lanostanes, ganoderic acids, lucidenic acids and australic acid are produced by G. austral (León et al. 2003, Jain \& Gupta 1984), but this medicinal Ganoderma species has not previously been recorded or cultivated in Thailand. In our study, we provide the optimal culture conditions suitable to cultivate this species in Thailand without controlled environments. Since this species is medicinally important and the growing substrate (rubber sawdust) is readily available in Thailand, cultivation of this species could provide an extra income to the local farmers in Thai villages (Thawthong et al. 2014).

In this paper, we detail G. australe from Thailand with morphological characteristics and phylogenetic data, and report for the first time in Thailand the optimal conditions for mycelia, spawn production and the cultivation of G. australe.

\section{Materials \& Methods}

\section{Mushroom collection and isolation}

The fruiting bodies of Ganoderma australe growing on decaying hardwood were photographed and collected from a mixed deciduous forest dominated by Shorea robtusa in Chiang Mai, Thailand. Detailed morphology of the specimens was recorded based on fresh material and documented by photographs. Morphological characteristics were recorded in the laboratory following Lodge et al. (2004) while colors were recorded following Ridgeway (Ridgeway 1912). Micro-morphological characteristics were observed using a compound microscope (Carl Zeiss ${ }^{\mathrm{TM}}$ SteREO Discovery.V8 Microscopes), while basidiospores were photographed using a Scanning Electron Microscope (SEM). Specimens were subsequently dried at $40{ }^{\circ} \mathrm{C}$ for 24 hours. The dried samples were kept in sealed plastic bags with silica gel and deposited in the Mae Fah Luang University herbarium (herb. MFLU) (voucher no. MFLU 13-0534).

Mycelia were isolated following the method described by Stamets (2000). A pure culture was obtained from fresh fungal tissues placed on potato dextrose agar (PDA) and incubated at $30{ }^{\circ} \mathrm{C}$ for 10 days. After the agar surface was fully covered with the fungal mycelium, the stock pure culture was deposited in the culture collection of Mae Fah Luang University (MFLUCC) (voucher no. MFLUCC 12-0527) and maintained at $4{ }^{\circ} \mathrm{C}$ for use in future studies.

\section{DNA extraction, sequencing and phylogenetic analysis}


Pure cultures were isolated in PDA media and incubated at $30{ }^{\circ} \mathrm{C}$ until the mycelia completely covered the agar surface. The mycelia (about $50 \mathrm{mg}$ ) were scraped off into a $1.5 \mathrm{ml}$ micro centrifuge tube. DNA was extracted from fresh mushroom mycelia using a Biospin Fungus Genomic DNA Extraction Kit (BioFlux ${ }^{\circledR}$ ). The internal transcribed spacer (ITS) regions of nuclear rDNA were amplified by polymerase chain reaction (PCR) with primers ITS5 and ITS4 under the following thermal cycles; $94^{\circ} \mathrm{C}$ for $5 \mathrm{~min}$, for the denaturation step, followed by 35 cycles of $94{ }^{\circ} \mathrm{C}$ for 30 secs, $55{ }^{\circ} \mathrm{C}$ for $30 \mathrm{secs}$, with a final extension step of $70{ }^{\circ} \mathrm{C}$ for $10 \mathrm{mins}$. The purified PCR products were directly sequenced. ITS 5 and ITS 4 were used to sequence both strands of the DNA molecules. The sequencing of PCR products was carried out at Beijing Bai Mai Hui Kang Biological Engineering Technology Co. Ltd (Beijing, P. R. China). The nuclear ribosomal Internal Transcribed Spacer region (nrITS) of the mushroom was amplified and the sequence was deposited in GenBank under the accession number KP142173. Facesoffungi number was obtained as detailed in Jayasiri et al. (2015).

Sequences obtained from GenBank (Table 1) and the sequences obtained from our samples of G. australe were used for the analyses. Sequences were aligned using Bioedit v. 7.0.9 (Hall 1999) and Clustal X (Thompson et al. 1997). Alignments were manually adjusted to allow maximum sequence similarity. Gaps were set as missing data. A phylogenetic tree was constructed using the PUAP beta 10 software version 4.0 (Swofford 2002). Clade results from parsimony analyses were assessed by ML bootstraps analysis with 1,000 replicates random sequence additions. The resulting trees were printed with TreeView v. 1.6.6. (Page 1996). Parsimony bootstrap values above 50\% are shown above the branches.

Table 1 Taxa information and GenBank accession numbers of Ganoderma specimens used in molecular phylogenetic analysis.

\begin{tabular}{lll}
\hline Fungal species & Fungal strains & GenBank accession number (ITS) \\
\hline Ganoderma adspersum & 12 & AJ006685 \\
G. adspersum & PF263 & JN176908 \\
G. adspersum & PF264 & JN176879 \\
G. adspersum & PF268 & JN176887 \\
G. adspersum & PF272 & JN176898 \\
G. adspersum & PF273 & JN176884 \\
G. adspersum & PF275 & JN176903 \\
G. adspersum & PF288 & JN176905 \\
G. annulare & KCTC 16803 & JQ520160 \\
G. applanatum & KA13-1209 & KR673681 \\
G. australe & JM98/339 & AF255119 \\
G. australe & JM98/19 & AF255120 \\
G. australe & JM95/6 & AF255121 \\
G. boninense & WD2085 & KJ143906 \\
G. enigmaticum & CMW43669 & KR183855 \\
G. fornicatum & BCRC35374 & JX840349 \\
G. gibbosum & AS5.624 type 1 & AY593854 \\
G. gibbosum & AS5.624 type 2 & AY593855 \\
G. gibbosum & AS5.624 type 3 & AY593856 \\
G. gibbosum & AS5.624 type 4 & AY593857 \\
G. gibbosum & S04 & KU055650 \\
G. gibbosum & KA12-1269 & KR673513
\end{tabular}




\begin{tabular}{lll} 
G. japonicum & Gja-1 & GU213475 \\
G. lingzhi & M9724 & KU310901 \\
G. lobatum & ATCC42985 & JQ520165 \\
G. lucidum & TH1197 & AF255150 \\
G. martinicense & LIP SW-Mart08-44 & KF963257 \\
G. mastoporum & GDGM25720 & JX195201 \\
G. meredithae & ASI 7140 & JQ520191 \\
G. miniatocinctum & 337024 & KM220586 \\
G. mirabile & CBS 218.36 & JQ520192 \\
G. mutabile & Yuan2289 & JN383977 \\
G. orbiforme & BCC22324 & JX997990 \\
G. oregonense & CBS26688 & JQ781876 \\
G. ryvardense & HKAS58053 & HM138671 \\
G. sinense & Zizhi & KT906369 \\
G. tornatum & CBS109679 & JQ520217 \\
G. tsuga & ATCC64794 & JQ675674 \\
G. zonatum & FL-02 & KJ143921 \\
G. australe & MFLUCC 12-0527 & KP142173 \\
Trametes versicolor & KUC8714 & HM008935 \\
Pycnoporus cinnabarinus & CIRM-BRFM 237 & FJ234205 \\
\hline
\end{tabular}

*Sequences generated in this study are in bold.

\section{Antimicrobial activity}

For the purposes of studying the antimicrobial activities, mushroom extracts were prepared from the mycelia. Ten agar plugs of the mushroom mycelia were transferred to $250 \mathrm{ml}$ of potato dextrose broth (PDB) and malt extract broth (MEB), and incubated with shaking $(150 \mathrm{rpm})$ at $30{ }^{\circ} \mathrm{C}$ for 14 days. To obtain the extract, the mycelia was harvested using sterilized filter paper (Whatman No. 1). The mycelia was collected and extracted by $50 \mathrm{ml}$ of $0.1 \mathrm{~N}$ of ethyl acetate (EtOAc). The extraction was performed twice. The extracts obtained were concentrated by air-drying $(\sim 2 \mathrm{ml})$ and were stored at $-20{ }^{\circ} \mathrm{C}$ until use.

The crude extracts were tested for antibacterial activity using a paper disc diffusion technique (Kirby et al. 1957). The testing gram positive and negative bacteria used were Staphylococcus aureus TISTR1466, Escherichia coli TISTR780, Micrococcus luteus TISTR884, Bacillus subtilis TISTR008, Pseudomonas aeruginosa TISTR781, and Salmonella typhimurium TISTR292. For an assay, the testing bacteria $\left(\sim 10^{6} \mathrm{CFU} / \mathrm{ml}\right)$ were transferred to nutrient agar by swabbing. After that, $100 \mu 1$ of each crude extract were poured onto a sterile paper disc, and the paper discs were air-dried for $20 \mathrm{~min}$ before being placed on the test plates. Inhibitory activity was then determined based on the appearance of clear zones surrounding the disc papers observed under a dissecting microscope. The diameter $(\mathrm{mm})$ of the clear zones was recorded. The experiment were carried out in five replicates.

\section{Effect of media for mycelia growth}

Six different solid media were used in this experiment; yeast extract agar (yeast extract $3 \mathrm{~g}$, peptone $5 \mathrm{~g}$ ), yeast extract peptone dextrose agar (yeast extract $10 \mathrm{~g}$, peptone $20 \mathrm{~g}$, dextrose $20 \mathrm{~g}$ ), corn meal agar (corn $17 \mathrm{~g}$ ), oatmeal agar (oat 60g), potato dextrose agar (potato $4 \mathrm{~g}$, dextrose 20g), and malt extract agar (malt extract $20 \mathrm{~g}$, peptone $6 \mathrm{~g}$, dextrose $20 \mathrm{~g}$ ). All media were mixed with $15 \mathrm{~g}$ of agar and $1,000 \mathrm{ml}$ distilled water. $\mathrm{pH}$ was adjusted to 6.5 by using $1 \mathrm{~N} \mathrm{HCl}$ and $1 \mathrm{~N} \mathrm{NaOH}$ (Kumla et al. 2013). Mycelia discs were cut half a centimeter $(0.5 \times 0.5 \mathrm{~cm})$ from the advancing margin of 14 day-old pure cultures and were placed on the centre of each medium. Petri dishes were incubated 
in darkness at $30{ }^{\circ} \mathrm{C}$ for 10 days. The optimal media for mycelia growth, density, and mushroom growth were measured. The experiment was carried out in five replicates.

\section{Effect of temperature and pH for mycelia growth}

The growth of G. australe mycelium was evaluated in darkness at different temperatures (20, 25,30 , and $35^{\circ} \mathrm{C}$ ) in order to find the optimal temperature for mycelial growth. $\mathrm{pH}$ was adjusted to $5,6,7$, and 8 by adding $1 \mathrm{~N} \mathrm{NaOH}$. The culture was incubated at $30^{\circ} \mathrm{C}$ for 10 days. Colony diameter was measured and calculated. The experiment were carried out in five replicates. The experiment was carried out in five replicates.

\section{Grain media for inoculum production}

Five different types of cereal grains and agricultural wastes were used to determine the best grain media for the cultivation of G. australe. We followed the method of Luangharn et al. (2014) using sorghum (Sorghum bicolor L.), corn cobs (Zea mays L.), pearl millet (Pennisetum glaucum (L.) R. Br.), barley (Hordeum vulgare L.) and sawdust. The supplemented grain media for spawn production were prepared as described by Luangharn et al. (2014). The ingredients included $1 \mathrm{~kg}$ of cereal grain/sawdust, $12 \mathrm{~g}$ of $\mathrm{CaSO}_{4} \cdot 2 \mathrm{H}_{2} \mathrm{O}, 3 \mathrm{~g}$ of $\mathrm{CaCO}_{3}$, and $1.5 \mathrm{~L}$ tap water. The supplemented cereal grain/sawdust was divided into two types (Type 1: all ingredients were mixed with gypsum and $\mathrm{CaCO}_{3}$; Type 2: ingredients only). Each cereal grain/sawdust type was washed and soaked overnight, boiled for 15 minutes, and left to cool down for $20 \mathrm{~min}$. Fifty grams of each cereal grain/sawdust were filled into media bottles, autoclaved at $121{ }^{\circ} \mathrm{C}$ for $15 \mathrm{~min}$ Before inoculation, the cereal grain/sawdust bottles were shaken to prevent clump formation. Five plugs of active mycelial $(0.5 \mathrm{~cm}$-diameter) of active mycelia from a pure culture were placed into the upper side of the grain media bottles. Grain bottles were incubated in dark at $30^{\circ} \mathrm{C}$ for 10 days. The linear mycelium length was measured every 2 days for 10 days to estimate the growth rate. All the cereal grain experiments were carried out in five replicates.

\section{Bag preparation and fruiting body production}

Initially, sawdust of Para rubber (Hevea brasiliensis Mull-Arg.) was used as the main substrate. The growth substrate formula used is shown in Table 2. The components were mixed well and water was gradually added until the moisture content was around 65-75\%.900 g of sawdust substrate was deposited in thermo-stable polypropylene bags $(6.50 \times 12.50$ inch). The bags were punched to make holes $(\sim 5 \mathrm{~cm})$, and a plastic ring was used to make a bottle neck, which was plugged with cotton wool and paper, sealing the tops of the bags. The sawdust bags were sterilized in an autoclave at $15 \mathrm{psi}$ at $121{ }^{\circ} \mathrm{C}$ for $30 \mathrm{~min}$. After sterilization, the sawdust bags were allowed to cool for $12 \mathrm{hr}$. Control bags only contained sterilized sawdust.

Table 2 Composition of various organic and inorganic additives in the growing substrate.

\begin{tabular}{lll}
\hline Treatments & Source & Weight \\
\hline Rubber sawdust $(\mathrm{Kg})$ & - & 100 \\
Rice bran $(\mathrm{Kg})$ & Chiang Rai & 3 \\
Pumice sulfate $(\mathrm{g})$ & Thai green agro, Bangkok & 30 \\
Calcium carbonate $\left(\mathrm{CaCo}_{3}\right)(\mathrm{Kg})$ & Thai polychemical, Samutsakorn & 0.5 \\
& & \\
Magnesium sulfate & Mushroom farm, Pathumthani & 0.5 \\
$\left(\mathrm{MgSO}_{4}\right)(\mathrm{Kg})$ & & 30 \\
Brew's yeast $(\mathrm{g})$ & Mushroom farm, Pathumthani & 30
\end{tabular}




\begin{tabular}{lll} 
EM solution $(\mathrm{ml})^{\text {a }}$ & EM Kyusei, Saraburi & 300 \\
Molasses solution $(\mathrm{ml})^{\mathrm{b}}$ & Green Plana, Nonthaburi & 300 \\
\hline
\end{tabular}

Note. (a) = 10cc of EM solution was diluted with $300 \mathrm{ml}$ of water. (b) = 10cc of molasses solution was diluted with $300 \mathrm{ml}$ of water.

Five grams of master spawn were inoculated into the sawdust bags under aseptic conditions, after which the bags were closed tightly, and incubated at room temperature $\left(30 \pm 1{ }^{\circ} \mathrm{C}\right), 60-75 \%$ relative humidity and in the dark. After the mycelia completely colonized the substrate, the bags were moved to a shelf and opened. To maintain relative humidity, the bags were sprayed with water daily until the fruiting bodies had fully developed. Growth parameters such as timing of mycelial growth, primordial initiation, fruiting development and fructification period were recorded regularly. All the analyses were carried out in five replicates.

\section{Harvesting and yield data}

The mature (when the spore dust appears) mushroom fruiting bodies were manually harvested, counted and weighed daily. The number of primordia and fruiting bodies per bag were recorded. At the end of the batch (no more primodia are seen), yield data was determined (Royse 2010, LlarenaHernández et al. 2011, Mamiro \& Mamiro 2011).

\section{Data collection and statistical analysis}

Data analysis was carried out using statistical programs (SPSS) with five replicates. Data were collected for mycelial growth rate, optimal conditions, spawn production, primordia production, and duration from mature fruiting bodies to harvest and biological yield. All data were compared to obtain a mean separation using Tukey's test $(p<0.05)$ followed by post-hoc tests and expressed in a one-way ANOVA analysis using SPSS program (Softonic International SA, Barcelona, Spain).

\section{Results and Discussion}

\section{Mushroom morphology and isolation}

Ganoderma australe (Fr.) Pat., Bull. Soc. mycol. Fr. 5(2, 3): 65 (1889)

Figs $1-3$

\section{Facesoffungi number: FoF02906}

\section{Macro-morphological description}

Basidiocarp; 1-15 cm wide, 2-7cm long, 0.5-3 cm thick near the base. Pileus circular and smooth when present, applanate, spathulate and some flabelliform and clusters when young, dimidiate and semicircular of mature (Fig. 1a). Pileus surface; glabrous, glossy, convex, laccate, furrow and consistency hard when fresh, tough and light in weight when dry. Distinct concentric zones, light brown (6D4) to brown (6E8) at the centre, and slightly pale orange (5A3) to white (5A1) at the margin when young, become reddish brown (8E6) to dark brown (9F8) at the centre, dull red (8C4), pale red (7A3) to white (8A1) at margin when age as the upper and brown to dark brown when dried, separated by a layer of context. Brown to grey in winter or may fade as the weathering has destroyed the pigments in the pileus surface. Margin; soft, round, pale yellow (4A3) to grayish brown (5D3) and reddish grey (8B2), change to greyish orange (6E3) when touched. Up to $0.5-3 \mathrm{~cm}$ thick, thin lighter than the base, thickened towards the margin and downwards to the poreless marginal part of hymenophore. Stipe; $1.5-3.5 \mathrm{~cm}$ wide, 3-5 cm long, $1.3-3.3 \mathrm{~cm}$ thick, applanate with umbo and slightly extend at the base. Pore; angular, $4-6$ per $\mathrm{cm}$ in fresh, tube layer $0.2-1.2 \mathrm{~cm}$ long, 50-180 $\mu \mathrm{m}$ wall thick when dried. Pore surface; white (2A1) to pale yellow (2A3) in growing specimen and immediately discolored when bruised, cream to grayish brown (5D3) when fresh (Fig. 1b), brownish 
grey (5C2) to brown when dried. Pure cultures turned white after incubation at $30^{\circ} \mathrm{C}$ for 10 days (Fig. 1c). Odor; distinctive odor when dried. Substrate; on dead standing tree.

\section{Micro-morphological description}

Microscopic structures of G. australe strain MFLUCC 12-0527 are shown in Fig. 2. Hyphal system; tri-dimitic hyphae; contextual generative hyphae, binding and skeletal hyphae (Fig. 2d), with clamps connections (Fig. 2e), 1-6 $\mu \mathrm{m}$ wide, hyaline, thin wall; skeletal hyphae hyaline to pale brown to brown, thicker wall 2-7 $\mu \mathrm{m}$ wide. Basidiospores; mostly broadly ellipsoid at maturity, some distinctly tapering at the distal end, truncate, double wall, thick-walled inner endosporium; 4-11 $\times$ 3-7 $\mu \mathrm{m}$ (Fig. 2a-c), reddish brown. Basidia; not observed.
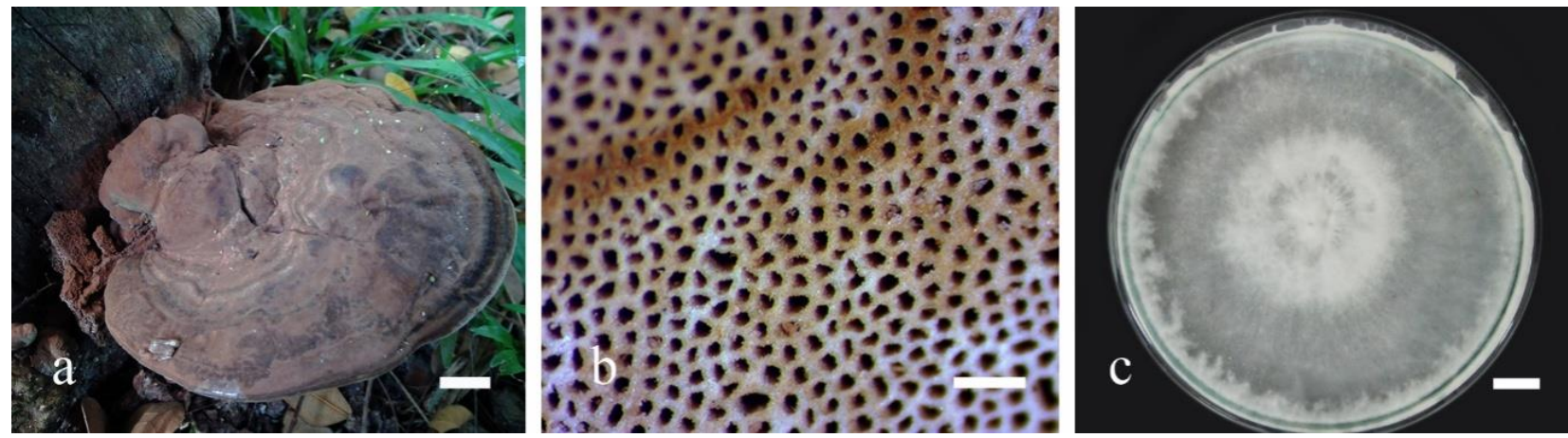

Figure 1 - Basidiocarp morphology of Ganoderma australe strain MFLUCC 12-0527. a. Mature basidiocarps in the field. b. pore characteristics. c. culture incubated at $30{ }^{\circ} \mathrm{C}$ for 10 days. - Bars $\mathrm{a}=$ $2 \mathrm{~cm}, \mathrm{~b}=500 \mu \mathrm{m}, \mathrm{c}=1 \mathrm{~cm}$.
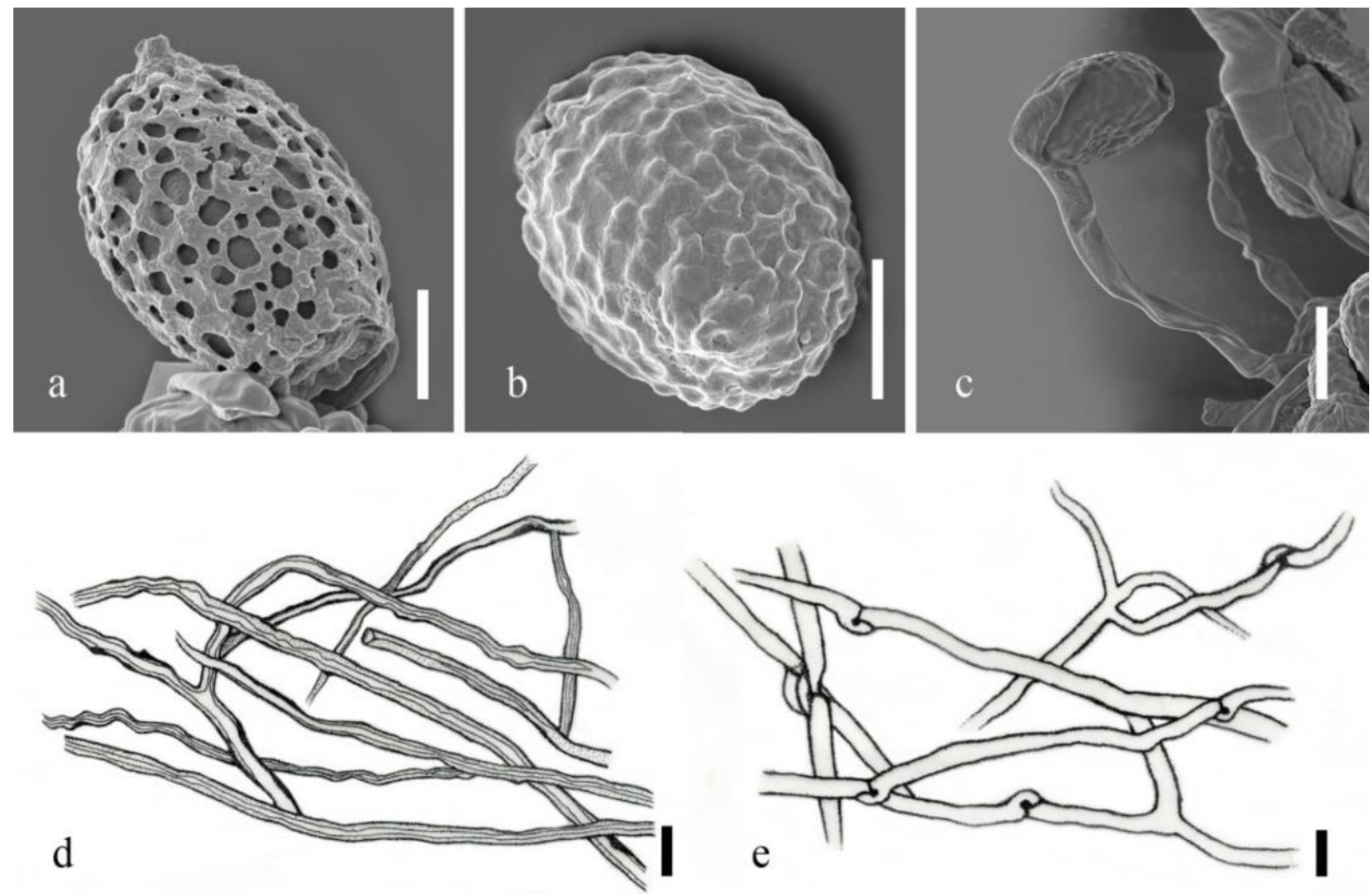

Figure 2 - Micro-characteristics of Ganoderma australe strain MFLUCC 12-0527. a-c. SEM micrograph of basidiospores. $d$. hyphae from trama. e. clamp connections from trama. Bars $a-b=2$ $\mu \mathrm{m}, \mathrm{c}=4 \mu \mathrm{m}, \mathrm{d}-\mathrm{e}=10 \mu \mathrm{m}$. 


\section{Phylogenetic analysis}

Partial sequences of the internal transcribed spacer (ITS) were used to resolve the phylogenetic placement of G. australe (Fig. 3). The alignment dataset comprised of 42 taxa, which include 27 species with 2 outgroup taxa (Trametes versicolor KUC8714 and Pycnoporus cinnabarinus FJ234205). The maximum parsimony dataset consists of 723 characters, of which 387 were constant, 121 variable characters were parsimony-informative and 215 characters were parsimony-uninformative. The phylogenetic analysis showed that our Ganoderma strain MFLUCC 12-0527 grouped in the $G$. australe clade with high support (91\% bootstrap support). Our results strongly corresponded to the geographic origin of the isolates reported from Thailand (Moncalvo \& Buchanan 2008), but $G$. australe has not been reported from Thailand with morphological characteristics and phylogenetic data.

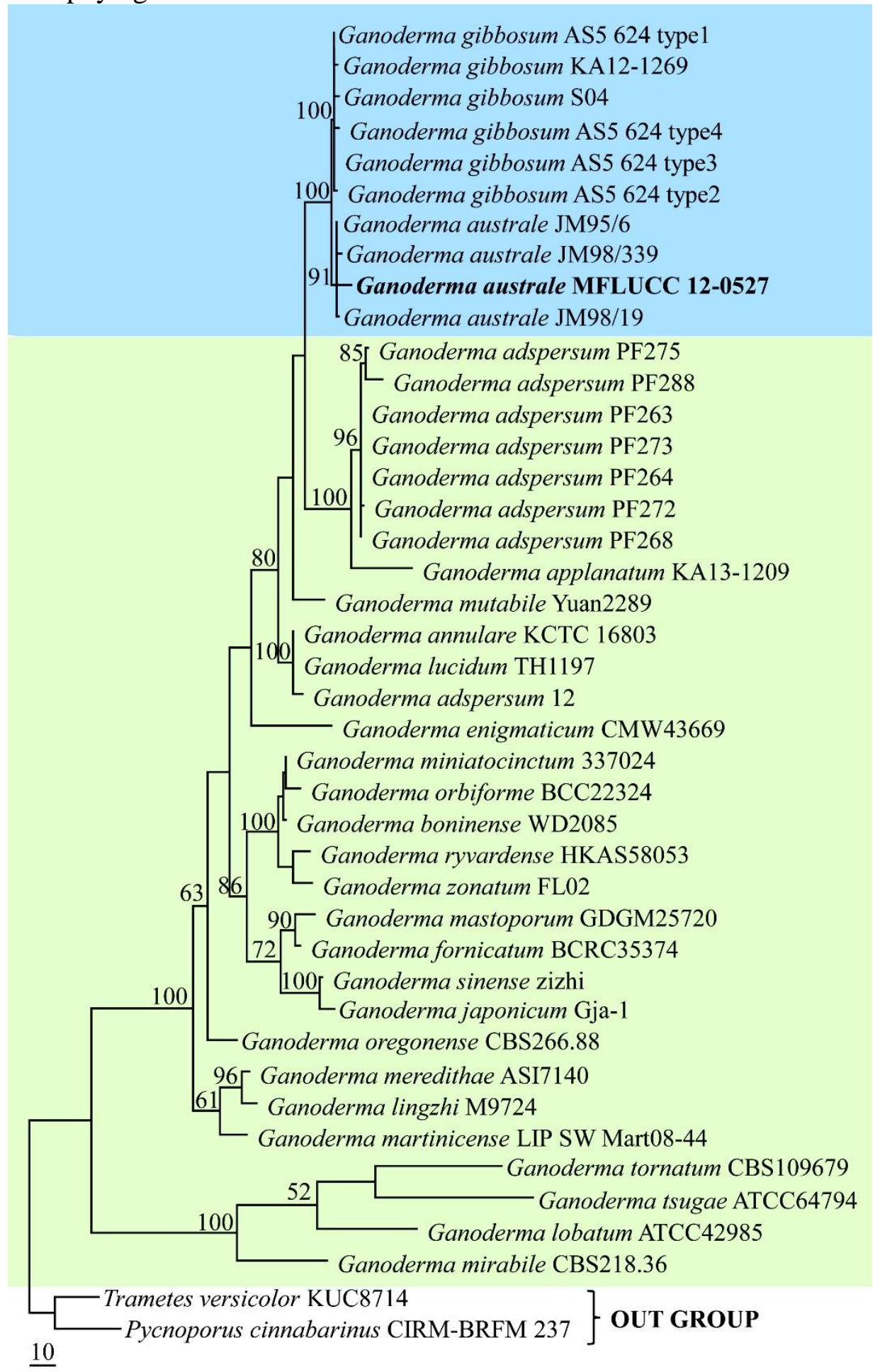


Figure 3 - Phylogenetic tree showing the phylogenetic position of Ganoderma australe strain MFLUCC 12-0527 in comparison with available ITS-1-5.8S-ITS2 rDNA sequence data of Ganoderma in GenBank. Bootstrap support values for maximum parsimony equal or higher than 50 $\%$ are defined above the nodes. Data were analyzed with random addition sequence and unweighted parsimony, and gaps were treated as missing data. The tree is rooted with Trametes versicolor KUC8714 and Pycnoporus cinnabarinus FJ234205.

\section{Antimicrobial activity}

The antibacterial effects of the extract of G. australe strain MFLUCC 12-0527 were tested against six bacterial pathogens (three Gram-positive and three Gram-negative). As summarized in Table 3, the extracts were able to inhibit the growth of four of the bacteria tested. The mycelial extracts obtained from mycelia of G. australe strain MFLUCC 12-0527 grown on both PDB and MEB media had a strong inhibition spectrum against $M$. luteus, B. subtilis $S$. aureus and $S$. typhimurium, while neither were effective against $E$. coli or $P$. aeruginosa. Suay et al. (2000) found a higher proportion of antibacterial activities in representatives of the family Ganodermatales than several orders encompassing basidiomycete. Smania et al. (2007) also reported that of G. australe strongly inhibited the growth of Gram-positive bacteria, and those methyl esters were active against Gram-negative bacteria. However, inhibitory activity seems to depend on i) the isolate, ii) culture media (and culture conditions), and iii) the type of microorganism.

Table 3 Antimicrobial activities of Ganoderma australe strain MFLUCC 12-0527 against some microorganisms on different aqueous culture media.

\begin{tabular}{|c|c|c|}
\hline \multirow[t]{2}{*}{ Microorganism strains } & \multicolumn{2}{|c|}{ MFLUCC 12-0527 } \\
\hline & $\begin{array}{l}\begin{array}{l}\text { Potato } \\
\text { (PDB) }\end{array} \\
\text { PDtrose }\end{array}$ & $\begin{array}{l}\text { Malt extract broth } \\
(\text { MEB })\end{array}$ \\
\hline Staphylococcus aureus & $0.75 \pm 0.05^{\mathrm{bB}}$ & $0.75 \pm 0.03^{\mathrm{bB}}$ \\
\hline Escherichia coli & $0.00^{\mathrm{cC}}$ & $0.00^{\mathrm{dC}}$ \\
\hline Micrococcus luteus & $1.20 \pm 0.03^{\mathrm{aA}}$ & $1.11 \pm 0.02^{\mathrm{aA}}$ \\
\hline Bacillus subtilis & $0.81 \pm 0.18^{\mathrm{bB}}$ & $0.70 \pm 0.06^{\mathrm{cB}}$ \\
\hline Pseudomonas aeruginosa & $0.00^{\mathrm{cC}}$ & $0.00^{\mathrm{dC}}$ \\
\hline Salmonella typhimurium & $0.70 \pm 0.00^{\mathrm{bB}}$ & $0.72 \pm 0.04^{\mathrm{bcB}}$ \\
\hline
\end{tabular}

Note. Values in the same letter differ significantly according to Tukey's multiple range test ( $p<$ $0.05)$. Inhibition zone values were indicated in centimeter $(\mathrm{mm})$. Values represent mean (mean $\pm \mathrm{SD}$ ) of five replicates of each strain on different aqueous media.

\section{Effect of media on mycelia growth}

The effects of the six-different media on the mycelial growth of G. australe strain MFLUCC 12-0527 is shown in Table 4. After 10 days of incubation, the mushroom mycelia were able to grow well on PDA medium $(8.80 \mathrm{~mm} /$ day), density (5+); followed by YEA $(8.40 \mathrm{~mm} /$ day $)$, density (4+); MEA and OMA (7.50 mm/day), density (3+); YEPD and CMA (6.40 mm/day), density (3+). These results agree with the Jo et al. (2009) study of $G$. applanatum, where mycelia growth was shown to be optimal on PDA medium.

Table 4 Effect of various solid media on mycelia growth $(\mathrm{mm})$ and mycelial growth rate $(\mathrm{mm} /$ day) of Ganoderma australe strain MFLUCC 12-0527. Values with the same letter are not significantly different $(p<0.05)$ according to Tukey's test. 


\begin{tabular}{llll}
\hline Culture media & Colony diameter & Growth rate & Mycelial density \\
\hline PDA & $14.95 \pm 0.09^{\mathrm{a}}$ & 8.80 & $5+$ \\
MEA & $9.96 \pm 0.06^{\mathrm{b}}$ & 7.50 & $3+$ \\
YEA & $10.01 \pm 0.07^{\mathrm{b}}$ & 8.40 & $4+$ \\
CMA & $5.14 \pm 0.12^{\mathrm{c}}$ & 6.40 & $3+$ \\
OMA & $9.98 \pm 0.23^{\mathrm{b}}$ & 7.50 & $3+$ \\
YEPD & $9.97 \pm 0.26^{\mathrm{b}}$ & 6.40 & $3+$ \\
\hline
\end{tabular}

Note. PDA- potato dextrose agar; MEA- malt extract agar; YEA- yeast extract agar; CMA- corn meal agar; OMA- oatmeal agar; YEPD- yeast extract peptone dextrose agar.

\section{Effect of temperature on mycelia growth}

Our results showed that mushroom mycelia were able to grow at all temperatures within a range of $20-35^{\circ} \mathrm{C}$. The best temperature for mycelia growth of $G$. australe was shown to be $30^{\circ} \mathrm{C}$, with a growth rate of $8.83 \pm 0.12 \mathrm{~mm} /$ day (Table 5). Other studies have also shown $30{ }^{\circ} \mathrm{C}$ to be the best temperature for the mycelia growth of G. applanatum (2009), Laetiporus sulphureus (Bull.: Fr.) Murrill (2014), and Pleurotus giganteus (Berk.) Karunarathna \& Hyde (Kumla et al. 2013).

Table 5 Mycelial growth rate (mm/day) of Ganoderma australe strain MFLUCC 12-0527 at different temperatures. Values with the same letter are not significantly different $(p<0.05)$ according to Tukey's test.

\begin{tabular}{ll}
\hline Temperature $\left({ }^{\circ} \mathbf{C}\right)$ & Mycelial growth rate \\
\hline 20 & $5.28 \pm 0.18^{\mathrm{c}}$ \\
25 & $8.18 \pm 0.24^{\mathrm{b}}$ \\
30 & $8.83 \pm 0.12^{\mathrm{a}}$ \\
35 & $5.14 \pm 0.14^{\mathrm{c}}$ \\
\hline
\end{tabular}

\section{Effect of pH on mycelia growth}

The effects of $\mathrm{pH}$ on the mycelia growth of $G$. australe strain MFLUCC 12-0527 are shown in Table 6. The fastest and densest mycelial growth was observed in alkaline media of $\mathrm{pH} 7-8$. Several studies have reported the optimal $\mathrm{pH}$ range for mycelia growth of various Ganoderma species to be pH 5-9 (Jo et al. 2009, Jayasinghe et al. 2008, Cho et al. 1993, Jeong et al. 2009).

Table 6 Mycelia growth rate (mm/day) of Ganoderma australe strain MFLUCC 12-0527 under different $\mathrm{pH}$ conditions. Values with the same letter are not significantly different $(p<0.05)$ according to Tukey's test.

\begin{tabular}{ll}
\hline $\mathbf{p H}$ & Mycelia growth rate $(\mathbf{m m} /$ day $)$ \\
\hline 5 & $7.24 \pm 0.66^{\mathrm{b}}$ \\
6 & $7.49 \pm 0.38^{\mathrm{b}}$ \\
7 & $8.73 \pm 0.04^{\mathrm{a}}$ \\
8 & $8.75 \pm 0.03^{\mathrm{a}}$ \\
\hline
\end{tabular}

\section{Effect of different grain substrates on inoculum (spawn) production}

The mycelial growth rates of G. australe strain MFLUCC 12-0527 grown on five different grain substrates are shown in Table 7. For type 1 (all ingredients are mixed with gypsum and $\mathrm{CaCO}_{3}$ ), 
the fastest growth in terms of mycelia extension was obtained on sorghum and barley $(5.00 \mathrm{~mm} /$ day $)$, followed by corn cobs $(4.87 \mathrm{~mm} /$ day $)$, pearl millet $(4.73 \mathrm{~mm} /$ day $)$ and sawdust $(4.40 \mathrm{~mm} /$ day $)$. For type 2 (ingredients only), the highest rate of mycelia growth was observed on sorghum (6.61 $\mathrm{mm} /$ day $)$, followed by barley $(5.65 \mathrm{~mm} /$ day $)$, corn cobs $(5.38 \mathrm{~mm} /$ day $)$, pearl millet $(5.08 \mathrm{~mm} /$ day $)$ and sawdust ( $5 \mathrm{~mm} /$ day). Although our results show that G. australe strain MFLUCC 12-0527 can be successfully grown on a range of substrates, the best growth results were recorded for sorghum or a mix of sorghum and barley. These findings are in agreement with the results of Kumla et al. (2013) who showed that sorghum grain was the best substrate for spawn production of wild mushrooms cultivated in Thailand.

Table 7 Effect of different types of cereal grain media and sawdust on mycelia growth rate $(\mathrm{mm} /$ day) of Ganoderma australe strain MFLUCC 12-0527. Values with the same letter are not significantly different $(p<0.05)$ according to Tukey's test.

\begin{tabular}{lll}
\hline Cereal grains media & Type 1 & Type 2 \\
\hline $\begin{array}{l}\text { Sorghum bicolor L. } \\
\text { (Sorghum) }\end{array}$ & $5.00 \pm 0.66^{\mathrm{a}}$ & $6.61 \pm 1.09^{\mathrm{a}}$ \\
$\begin{array}{l}\text { Pennisetum glaucum (L.) R. Br. } \\
\text { (Pearl millet) }\end{array}$ & $4.73 \pm 0.52 \mathrm{bc}$ & $5.08 \pm 0.28 \mathrm{c}$ \\
$\begin{array}{l}\text { Zea mays L. } \\
\text { (Corn cobs) }\end{array}$ & $4.87 \pm 0.76^{\mathrm{b}}$ & $5.38 \pm 0.83^{\mathrm{bc}}$ \\
$\begin{array}{l}\text { Hordeum vulgare L. } \\
\text { (Barley) }\end{array}$ & $5.00 \pm 0.01^{\mathrm{a}}$ & $5.65 \pm 0.40^{\mathrm{b}}$ \\
Para rubber sawdust & $4.40 \pm 0.54^{\mathrm{c}}$ & $5.00 \pm 0.05^{\mathrm{c}}$ \\
\hline
\end{tabular}

Note. Type 1, all ingredients were mixed with gypsum and $\mathrm{CaCO}_{3}$; Type 2: ingredients only.

\section{Fructification}

Three fruiting cycles were obtained in all the five substrate bags during 6 months. In the first cycle, we observed that the mycelia fully covered and grew throughout the bag from the top to the bottom, after 16-18 days of incubation. The first set of primordia formed three days after the substrate bags were opened (Fig. 4a-b). After 14 days, young fruiting bodies had developed and pore characteristics were observed under the surface of the fruiting bodies (Fig. 4c-d). After 50-55 days, mature fruiting bodies had developed in the substrate bags (Fig. 4e-f). After fruiting bodies were harvested, in order to induce mycelial growth and another fruiting cycle, the bags of substrate were ventilated daily for 3 days without being sprayed with water. Previous studies reported that Ganoderma grows best in substrate with a moisture content of 70\% (Peksen \& Yakupoglu 2009). The mushroom yield of the first cycle, at $115.04 \mathrm{~g}$, was higher than the second and third cycles, which produced yields of $72.01 \mathrm{~g}$ and $36.47 \mathrm{~g} \mathrm{~kg}^{-1}$ respectively (Table 8). Normally, a harvest period of Ganoderma species is 90 days (Peksen \& Yakupoglu 2009), while the higher numbers of primordia (12-13 primordia) and fruiting bodies were produced during a short period of time in the first (55 days) and second cycles (68 days), whereas only five primordia were produced in the third cycle. Mycelia were observed only on the substrate at the top of the bags. No primordia were produced when $100 \%$ sawdust substrate was used as the control. An initial stage of primordia formation is the most critical step (Stamets 2000). This mushroom strain, moisture content should be between 60 $75 \%$, below $40 \%$ results in slow mycelial growth. Our mushroom production (three cycles) results are in accordance with the results of Erkel (2009) while the production observed in our study is lower than that of G. lucidum (Zmitrovich et al. 2006) and G. neojaponicum (Zhou \& Zhang 2015). 

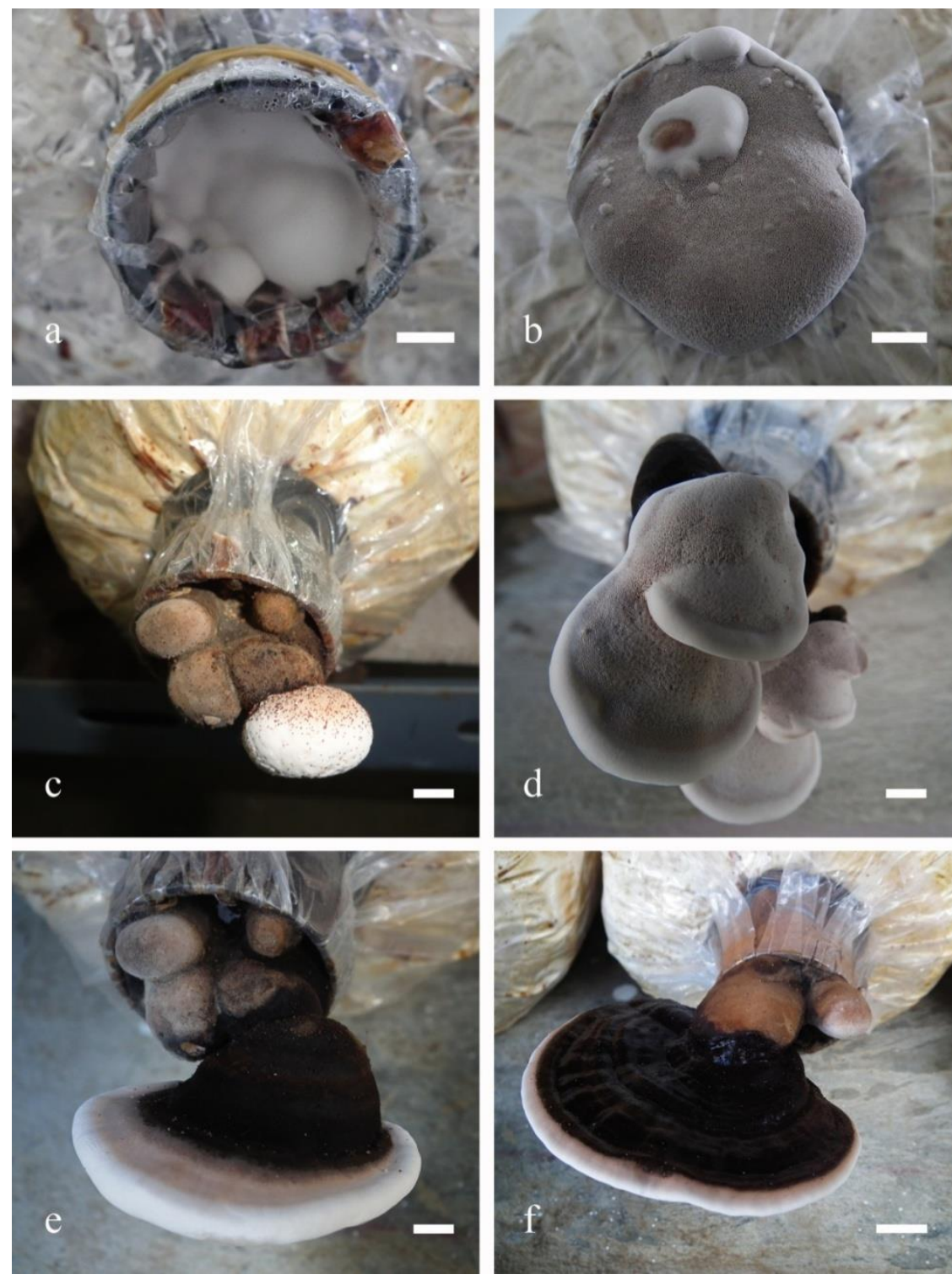

Figure 4 - Ganoderma australe strain MFLUCC 12-0527 production. a-b. primordial production (4-5 days after the substrate bags are opened). $\mathrm{c}-\mathrm{d}$. primordia developing into young fruiting bodies. e-f. mature fruiting bodies. - Bars: $a-f=1 \mathrm{~cm}$.

Table 8 Fruiting body production of Ganoderma australe strain MFLUCC 12-0527 on sawdust substrate bags (three fruiting cycles).

\begin{tabular}{llll}
\hline Contents & \multicolumn{3}{l}{ Fruiting bodies development } \\
\cline { 2 - 4 } & $\mathbf{1}^{\text {st }}$ cycle & $\mathbf{2}^{\text {nd }}$ cycle & $\mathbf{3}^{\text {rd }}$ cycle \\
\hline Occurrence for primordia formation & $4-5$ days & $5-6$ days & $10-12$ days \\
Number of primordia & 12 & 13 & 5 \\
Number of mature fruiting bodies & 6 & 6 & 0 \\
Average wet weight & $115.04 \mathrm{~g}$ & $72.01 \mathrm{~g}$ & $36.47 \mathrm{~g}$ \\
Yield data* & $25.56 \mathrm{~g} \mathrm{Kg}^{-1}$ & $16.01 \mathrm{~g} \mathrm{Kg}^{-1}$ & $8.10 \mathrm{~g} \mathrm{Kg}^{-1}$ \\
\hline
\end{tabular}

$*$ Yield data $=$ total weight of mushrooms per kilogram of substrate. 


\section{Discussion}

This study reports a new record of Ganoderma australe strain MFLUCC 12-0527 from Thailand. The results of our study show the capability of extracts G. australe produce significant bioactive compounds. It might obviously a reliable source of a variety of biological actions on secondary metabolites such antimicrobial compounds to compete other organisms by exhibited a broad spectrum of activity against Gram-positive and Gram-negative bacteria responsible for the most common bacterial diseases. In addition, we showed that $G$. australe grew best on PDA media, at a temperature of $25-30^{\circ} \mathrm{C}$ and at a $\mathrm{pH}$ of $7-8$. Although sorghum grain were the best grain substrate for G. australe spawn production, this fungus can be successfully be grown on a range of spawn substrates including cereal grains (sorghum, barley, corn cobs, pearl mille) and para rubber sawdust, which are cheap and readily available to small scale farmers in Thailand. Further studies will be carried out to optimize the growing substrate in order to increase the yield of this Thai G. australe. The results of this study will be helpful for the small-scale mushroom farmers in northern Thai villages as well as Laos, Cambodia and Myanmar, where similar climatic conditions persist for an additional income by cultivating this medicinal G. australe.

\section{Acknowledgements}

Kevin D. Hyde thanks the Chinese Academy of Sciences, project number 2013T2S0030, for the award of Visiting Professorship for Senior International Scientists at Kunming Institute of Botany. This study was financially supported by the Chinese Ministry of Science and Technology, under the 12th 5-year National Key Technology Support Program (NKTSP)2013BAB07B06 integration and comprehensive demonstration of key technologies on Green Phosphate-mountain Construction; the CGIAR Research Program 6: Forest, Trees and Agroforestry; Thailand Research Fund grant - Taxonomy, Phylogeny and biochemistry of Thai Basidiomycetes (BRG 5580009), Center of Excellence in Fungal Research and Scientific Technological Instruments Center of Mae Fah Luang University and Mushroom Research Foundation (MRF), Chiang Rai, Thailand. Mae Fah Luang University Culture Collection (MFLUCC) and Mae Fah Luang University Herbarium (MFLU Herb.) are thanked for providing facilities. Naritsada Thongklang, Kritsana Jatuwong, Anan Thawthong, Asanaka R. Bandara, Kalani K. Hapuarachchi and Saowaluck Tibpromma are acknowledged for their help on fieldwork and valuable suggestions.

\section{References}

Adaskaveg JE, Gilbertson RL. 1986 - Cultural studies and genetics of sexuality of Ganoderma lucidum and G. tsugae in relation to the taxonomy of the G. lucidum complex. Mycologia 78, 694-704.

Anonymous. 1955 - Shen Nong materia medica, 102-200 A. D. (E. Han). Shen Nong Materia Medica. Beijing, People's Hygiene Press. Chinese.

Baby S, Johnson AJ, Govindan B. 2015 - Secondary metabolites from Ganoderma. Phytochemistry 114, 66-101.

Batra P, Sharma AK, Khajuria R. 2013 - Probing lingzhi or reishi medicinal mushroom Ganoderma lucidum (higher Basidiomycetes): a bitter mushroom with amazing health benefits. International Journal of Medicinal Mushrooms 15, 127-43.

Buchanan PK, Wilkie JP. 1995 - Taxonomy of New Zealand Ganoderma: two non-laccate species. In: Buchanan PK, Hseu RS, Moncalvo JM, editors. Ganoderma: Systematics, Phytopathology and Pharmacology. Proceedings of contributed symposia 59A, B, fifth international mycological congress; 1994 Aug 14-21; Canada. Vancouver.

Chang ST, Buswell JA. 1999 - Ganoderma lucidum (lingzhi), a mushrooming medicinal mushroom. International Journal of Medicinal Mushrooms 11, 1319-1346.

Chang ST, Wasser SP. 2012 - The role of culinary-medicinal mushrooms on human welfare with pyramid model for human health. International journal of medicinal mushrooms 14(2), 95134. 
Cho SM, Seo GS, Yu SH, Yoo ID et al. 1993 - Morphological characterization and culture conditions of a white mutant of Ganoderma lucidum. Kor. Applied microbiology and biotechnology 21, $520-526$.

Cilerdzic J, Kosanic M, Stajić M, Vukojevic J et al. 2016 - Species of genus Ganoderma (Agaricomycetes) fermentation broth: A novel antioxidant and antimicrobial agent. International Journal of Medicinal Mushrooms 18, 397-404.

De Silva DD, Rapior S, Fons F, Bahkali AH et al. 2012a-Medicinal mushrooms in supportive cancer therapies: an approach to anti-cancer effects and putative mechanisms of action. Fungal Diversity 55, 1-35.

De Silva DD, Rapior S, Hyde KD, Bahkali AH. 2012b - Medicinal mushrooms in prevention and control of diabetes mellitus - a review. Fungal Diversity 56, 1-29.

De Silva DD, Rapior S, Sudarman E, Stadler M et al. 2013 - Bioactive metabolites from macrofungi: ethnopharmacology, biological activities and chemistry. Fungal Diversity 62, 1-40.

El-Fallal AA, El-Sayed AKA, El-Esseily SR. 2015 - First record of two Ganoderma species from North East Nile Delta-Egypt. Mycosphere 6, 248-259.

Erkel EI. 2009 - The effect of different substrate mediums on yield of Ganoderma lucidum (Fr.) Karst. Journal of Food Agriculture and Environment 7, 841-844.

Fatmawati S, Shimizu K, Kondo R. 2010 - Ganoderic acid Df, a new triterpenoid with aldose reductase activity from the fruiting body of Ganoderma lucidum. Fitoterapia 81, 1033-1036.

Gao Y, Zhou S, Huang M, Xu, A. 2003 - Antibacterial and antiviral value of the genus Ganoderma P. Karst. species (Aphyllophoromycetideae): A review. International Journal of Medicinal Mushrooms 5, 235-246

Gerber AL, Smania Jr A, Monache FD, Biacchi Jr N et al. 2000 - Triterpenes and sterols from Ganoderma australe (Fr.) pat. (Aphyllophoromycetideae). International Journal of Medicinal Mushrooms 2, 303-311.

Hall TA. 1999 - BioEdit: a user-friendly biological sequence alignment editor and analysis program for Windows 95/98/NT. Nucleic acids symposium series 41, 95-98.

Hapuarachchi KK, Wen TC, Deng CY, Kang JC et al. 2015 - Mycosphere essays 1: Taxonomic confusion in the Ganoderma lucidum species complex. Mycosphere 6, 542-559.

Hiroo S. $2008-$ Method for cultivating Ganoderma amboinense. http://www.sumobrain.com/patents/jp/Method-cultivating-ganodermaamboinense/JP2008271917A.html

Isaka M, Chinthanom P, Kongthong S, Srichomthong K. 2013 - Lanostane triterpenes from cultures of the Basidiomycete Ganoderma orbiforme BCC 22324. Phytochemistry 87, 133-139.

Jain AC, Gupta SK. 1984 - The isolation of lanosta-7,9(11),24-trien-3b,21-diol from the fungus Ganoderma australe. Phytochemistry 23, 686-687.

Jayasinghe C, Imtiaj A, Hur H, Lee GW et al. 2008 - Favorable culture conditions for mycelial growth of Korean wild strains in Ganoderma lucidum. Korean Journal of Medical Mycology $36,28-33$.

Jayasiri SC, Hyde KD, Ariyawansa HA, Bhat J et al. 2015 - The faces of fungi database: fungal names linked with morphology, phylogeny and human impacts. Fungal Diversity 74, 3-18.

Jeong YT, Jeong SC, Yang BK, Islam R et al. 2009 - Optimal culture conditions for mycelial growth and exo-polymer production of Ganoderma applanatum. Mycobiology 37, 89-93.

Jo WS, Cho YJ, Cho DH, Park SD et al. 2009 - Culture conditions for the mycelial growth of Ganoderma applanatum. Mycobiology 37, 94-102.

Jo WS, Park HN, Park SH, Jung HY et al. 2010 - Fruit-body production of Ganoderma neojaponicum by sawdust cultivation. Korean Journal of Medical Mycology 38, 199-201.

Kaliyaperumal M, Kalaichelvan PT. 2008 - Ganoderma australe from southern India. Microbiology. Research 163, 286-292.

Kamra A, Bhatt AB. 2013 - First attempt of an organic cultivation of red Ganoderma lucidum under subtropical habitat and its economics. International Journal of Pharmacy and Pharmaceutical Sciences 5, 94-98. 
Karsten PA. 1881 - Enumeralio boletinearum et polyporearum fennicarum, systemate novo dispositarum. Revue Mycologique 3, 16-19.

Kirby WMM, Yoshihara GM, Sundsted KS, Warren JH. 1957 - Clinical usefulness of a single disc method for antibiotic sensitivity testing. Antibiotics Annual 1956, 892-897.

Kumla J, Suwannarach N, Jaiyasen A, Bussaban B et al. 2013 - Development of an edible wild strain of Thai oyster mushroom for economic mushroom production. Chiang Mai Journal of Science 40, 161-172.

León F, Valencia M, Rivera A, Nieto I et al. 2003 - Novel cytostatic lanostanoid triterpenes from Ganoderma australe. Helvetica Chimica Acta 86, 3088-3095.

Liu GM, Wu XL, Li JL, Pan XF et al. 2009 - Study on the spawn isolation and domestication of the wild Ganoderma tropicum (Jungh.) Bres. Natural Science Journal 27, $24-29$.

Liu W, Wang H, Pang X, Yao W et al. 2010 - Characterization and antioxidant activity of two lowmolecular-weight polysaccharides purified from the fruiting bodies of Ganoderma lucidum. International Journal of Biological Macromolecules 46, 451-457.

Llarena-Hernández RC, Largeteau M, Farnet AM, Minvielle N et al. 2011 - Phenotypic variability in cultivars and wild strains of Agaricus brasiliensis and Agaricus subrufescens; Proceedings of the 7th International Conference on Mushroom Biology and Mushroom Products (ICMBMP7) 2011; 2011 Oct 4-7; INRA, Bordeaux, France.

Lodge DJ, Ammirati FJ, O'Dell TE, Mueller GM. 2004 - Collecting and describing macrofungi. In: Mueller GM, Bills GF, Foster MS. Biodiversity of fungi inventory and monitoring methods. Elsevier Academic Press. London, 128-154.

Luangharn T, Karunarathna SC, Hyde KD, Chukeatirote E. 2014 - Optimal Conditions for Mycelia Growth of Laetiporus sulphureus sensu lato. Mycology 5, 221-227.

Mamiro DP, Mamiro PS. 2011 - Yield and mushroom size of Pleurotus ostreatus grown on rice straw basal substrate mixed and supplemented with various crop residues. Journal of Animal \& Plant Sciences 10, 1211-1218.

Mizushina Y, Takahashi N, Hanashima L, Koshino H et al. 1999 - Lucidenic acid O and lactone, new terpene inhibitors of eukaryotic DNA polymerases from a basidiomycete, Ganoderma lucidum. Bioorganic \& medicinal chemistry 7, 2047-2052.

Moncalvo JM, Buchanan PK. 2008 - Molecular evidence for long distance dispersal across the southern hemisphere in the Ganoderma applanatum-australe species complex (Basidiomycota). Mycological research 112, 425-436.

Moncalvo JM, Ryvarden L. 1997 - A nomenclatural study of the Ganodermataceae Donk. Syn Fung $11,1-114$.

Moncalvo JM, Wang HF, Hseu RS. 1995 - Gene phylogeny of the Ganoderma lucidum complex based on ribosomal DNA sequences. Comparison with traditional taxonomic characters. Mycological research 99, 1489-1499.

Ofodile LN, Kokubum NU, Grayer ORJ, Ogundipe OT et al. 2005 - Antimicrobial activity of some Ganoderma species from Nigeria. Phytotherapy research 19, 210-213.

Page RDM. 1996 - TreeView: an Application to display phylogenetic trees on personal computers. Computer applications in the biosciences 12, 357-358.

Papaspyridi LM, Katapodis P, Gonou-Zagou Z, Kapsanaki-Gotsi E et al. 2009 - Optimization of the medicinal mushroom $G$. australe biomass production using response surface methodology. Planta Medica 75, 946.

Paterson RRM. 2006 - Ganoderma - a therapeutic fungal biofactory. Phytochemistry. 67(18), 19852001.

Pegler DN. 2002 - Useful fungi of the world: the Ling-zhi - the mushroom of immortality. Mycologist 16, 100-101.

Peksen A, Yakupoglu G. 2009 - Tea waste as a supplement for the cultivation of Ganoderma lucidum. World Journal of Microbiology and Biotechnology 25, 611-618. 
Rai MK, Gaikwad S, Nagaonkar D, dos Santos CA. 2015 - Current advances in the antimicrobial potential of species of genus Ganoderma (higher Basidiomycetes) against human pathogenic microorganisms (review). International Journal of Medicinal Mushrooms 17, 921-32.

Ridgeway R. 1912 - Color standards and color nomenclature. Ridgeway, Washington DC, US.

Rofuli III NB, Cruz AGV, Medalla AP, Buenavista MTS. 2005 - Antimicrobial and antagonistic properties of Ganoderma lucidum (W. Curt.: Fr.) Lloyd. International Journal of Medicinal Mushrooms 7, 459-460.

Roy S, Jahan MAA, Das KK, Munshi SK et al. 2015 - Artificial cultivation of Ganoderma lucidum (Reishi medicinal mushroom) using different sawdust as substrates. American Journal of Bioscience 3, 178-182.

Royse DJ. 2010 - Effects of fragmentation, supplementation and the addition of phase II compost to 2nd break compost on mushroom (Agaricus bisporus) yield. Bioresource technology 101, 188-192.

Sadava D, Still DW, Mudry RR, Kane SE. 2009 - Effect of Ganoderma on drug-sensitive and multidrug-resistant small-cell lung carcinoma cells. Cancer Letters 277, 182-189.

Smania Jr A, Monache FD, Smania EDFA, Cuneo RS. 1999 - Antibacterial activity of steroidal compounds isolated from Ganoderma applanatum (Pers.) Pat. (Aphyllophoromycetideae) fruit body. International Journal of Medicinal Mushrooms 1, 325-330.

Smania E de FA, Monache FD, Yunes RA, Paulert R et al. 2007 - Antimicrobial activity of methyl australate from Ganoderma australe. Brazilian Journal of Pharmacognosy 17, 14-16.

Stamets P. 2000 - Growing gourmet and medicinal mushrooms. Ten Speed Press, California.

Suay I, Arenal F, Asensio FJ, Basilio A et al. 2000 - Screening of basidiomycetes for antimicrobial activities. Antonie van Leeuwenhoek 78, 129-140.

Swofford DL. 2002 - PAUP*. Phylogenetic analysis using parsimony (*and Other Methods), Version 4.0 beta version. Sinauer Associates, Sunderland, Massachusetts.

Tan WC, Kuppusamy UR, Phan CW, Tan YS et el. 2015 -Ganoderma neo-japonicum Imazeki revisited: Domestication study and antioxidant properties of its basidiocarps and mycelia. Scientific reports 5, 1-10.

Thawthong A, Karunarathna SC, Thongklang N, Chukeatirote E et al. 2014 - Discovering and domesticating wild tropical cultivatable mushrooms. Chiang Mai Journal of Science 41, 731764.

Thompson JD, Gibson TJ, Plewniak F, Jeanmougin F et al. 1997 - The CLUSTAL X windows interface: flexible strategies for multiple sequence alignment aided by quality analysis tools. Nucleic Acids Research 25, 4876-4882.

Upadhyay M, Shrivastava B, Jain A, Kidwai M et al. 2014 - Production of ganoderic Acid by Ganoderma lucidum RCKB-2010 and its therapeutic potential. Ann Microbial 64, 839-846.

Wang XC, Xi RJ, Li Y, Wang DM et al. 2012 - The species identity of the widely cultivated Ganoderma, G. lucidum (Ling-zhi) in China. PLoS ONE 7, 1-12.

Wasser SP. 2005 - Reishi or Ling Zhi (Ganoderma lucidum), Encyclopedia of dietary supplements. Marcel Dekker, New York, USA.

Yeh ZY. Chen ZC. 1990 - Preliminary investigation of Ganoderma australe (subgen. Elfvingia) in Taiwan. Taiwania 34, 127-41.

Zhiqun L, Ziwu C. 2011 - Study on the biological characteristics of mycelium of Ganoderma gibbosum. http://en.cnki.com.cn/Article_en/CJFDTOTAL-ZNTB201118034.htm

Zhou XW, Zhang YM. 2015 - Phylogenetic analysis of widely cultivated Ganoderma in China based on the mitochondrial V4-V6 region of SSU rDNA. Genetics and Molecular Research 14, 886897.

Zmitrovich IV, Didukh MY, Malysheva VF. 2006 - New medicinal Ganoderma mushroom from China: G. tsugae Murrill var. jannieae var. nov. (Aphyllophoro-mycetideae). International Journal of Medicinal Mushrooms 8, 161-172. 